\title{
Changes in the start-ups business models
}

\author{
Katarína Procházkováa ${ }^{1 *}$ \\ ${ }^{1}$ UEBA, Department of management, Dolnozemska cesta 1, 85235 Bratislava, Slovakia
}

\begin{abstract}
Research paper is summarizing results of project focus on business models and strategies of startups. The research was focused on identification of business models and strategies of startups. Research sample was creating from more than 70 startups at the beginning of the research and we finished research 3 years later with 53 startups. This research paper is partial output that analyze startups in global business environment in terms of doing business abroad and making strategic steps. The aim of paper is identify basic strategic steps and decision making of startups through selected indicators such as market presence and entry modes focusing on the last stage of research. Startups business model were also analyze and part of the output is mapping the shifts in business model Canvas of startups.
\end{abstract}

\section{Introduction}

Startups should be able to serve exponentially growing demand without a proportional increase in costs. The exponential growth possibility is also a typical feature of startups. Dave McClure, 2014 [1] claims that startup is a company that does not know exactly what its product is, who its customer is and how to make money. As soon as startup finds the exact answers to these three questions, it ceases to be a startup and becomes a real business Osterwalder and Pigneur [2] define a business model as a fundamental principle of creating, capturing, and offering the value to customers. The business model, the characteristics of business activities, and the specific strategy that should be global or at least regional, especially in the case of a startup from small local economies, are crucial in term of building the successful startup. The success of a startup is a scalable and saleable product that should be associated with effective market targeting and also branding and positioning. Building brand value today appears to be one of the basic strategic tools for the competitiveness of any business. It is also important to find the right investor for startup, and if you are getting financial resources, do not just rely on one source, but also search for other options like government programs, investors or venture capital.

\footnotetext{
${ }^{*}$ Corresponding author: katarina.prochazkova@euba.sk
} 


\section{The international strategies and business models of startup}

The development of new technologies and the rapid development of the Internet have brought the trend of global businesses that have managed to sell their products and services throughout the world over a short period. These businesses are called startups. Author Steve Blank [3,4] define a startup as a temporary institution created to find a repeatable and scalable business model

One of the strategies how to build a relationship with customers and create customer experience is through unique product or service and strong brand. Beyond building minimum valuable product is actually has to be useful and have people want to use it. Viability is not enough for small business software, services, hardware, or retail and customer products. Delightful products can adopted faster, encourage better word of mouth, and trigger better satisfaction. Users fall in love with delightful products. There are three area must come together to build this product: whole product approach, elegant design and focused quality. A great way to create Minimum Delightful Product is through an Experience Design Prototype, Fischer - Duane, 2016 [5]. A prototype is an early sample or model, which is launch to test a concept or process. Prototyping brings many advantages:

- $\quad$ Reduced time and costs: Prototyping can improve the quality of the specifications and requirements provided to customers. With prototyping, customers can anticipate higher costs, needed changes and potential project hurdles, and most importantly, potential end result disasters. Strong prototyping can ensure product quality and savings for years to come.

- Improved and increased user involvement: Most customers wants to feel like they are involved with the intricate details of their project. Prototyping requires user involvement and enables them to see and interact with a working model of their project. With prototypes, customers can give their immediate feedback, request project changes and alter model specifications. Prototyping most importantly helps eliminate misunderstandings and miscommunications during the development process.

On the other hand, a good product in good quality is always connected with effective branding. In the case of startups, marketing strategies and branding may not be a strength. A key startup recommendation is to focus on creating Minimum Viable Brand (MVB). A minimum viable brand is comprised of the core elements of a brand that are necessary to ensure internal focus and alignment as well as external relevance and differentiation. A framework for defining and developing MVB is the " 6 what's" published by Yohn, 2014 [6]. These 6 "what' $\mathrm{s}$ " are: what we stand for - our brand essence, what we believe in - our defining values, what people we seek to engage - our target audience(s), what distinguishes us - our key differentiators, what we offer - our overarching experience, what we say and show - our logo, look, and lines (messaging). According to an article by published Garber, Fund [7] minimum viable brand for startups is based on these key components: purpose, people, proposition, product and personality

All these strategic steps and decisions about product development, marketing, building brand, get a new users, keep and manage the existing customer, managing the customer segments, decision making about entry modes and how to scale are often gradual strategic steps that shape strategy but also trigger changes in business models.

According to Allan Afuah, 2003 [8], the business model is influenced by the activities the company performs and the resources it uses. The Allan Afuah's business model concept divides the business model into four key components: industry factors, resources, position, costs and activities.

According to W.M. Johnson, C.M. Christensen a H. Kagermann, 2008 [9], a business model consists of 4 elements that are interconnected and create value in the enterprises: benefit of customer value, profit formula, key resources and key processes. One of the most 
popular is business model Canvas designed by Osterwalder and Pigneur, 2010 [10]. This business model analyze business through nine blocks:

1. Key partners (Who are our key partners? Who are our key suppliers? Which key sources do we get from partners? Which key activities do partners hold?)

2. Key activities (What key activities are creating value? Our distribution channels? Customer relations? Revenue streams?)

3. Key resources (What key sources require our values? Our distribution channels? Customer relations? Revenue streams?)

4. Value proposition (What value do we bring to the customer? Which of the customer's issues do we help solve? Which customer needs do we satisfy? What packages of products and services do we offer to each customer segment?)

5. Channels (Through which channels do we reach our customers? How do we achieve them now? How are our channels integrated? Which of them work best? Which are the most cost-effective? How do we integrate them into our customer routine?

6. Customer relationship (What type of relationship do we expect from each customer segment to create and maintain with them? Which of them have we already created? How expensive? How are they integrated with the rest of the business model?)

7. Customer segments (For whom do we create value? Who are our most important customers?)

8. Costs structure (How much are you planning to spend on the product development and marketing? What is your current costs structure? What are key costs? What is your type of cost structure?)

9. Revenue stream (What value do customers want to pay for? What do they actually pay for? How do they pay? How would they like to pay? How much does each stream contribute to total revenue?

In this paper we focused on mapping of changes and shifts in business model Canvas of startups in time (synthesis aggregates results during 3 years period, research started with more than 70 startups and was finished with 53 startups).

\section{Research sample and research design}

During 2015 - 2018, 76 startups in Slovakia were analyzed in three stages, and their business models were questioned. The last stage of research was finished with 53 startups; the basic structure of samples is shown in Table 1.

Table 1. Structure of research sample - the last stage of research

\begin{tabular}{|c|c|c|}
\hline & Number (N) & $\%$ \\
\hline Number of startups & 53 & 100 \\
\hline \multicolumn{3}{|c|}{ Number of team members } \\
\hline $1-3$ & 9 & 17 \\
\hline $4-6$ & 19 & 37 \\
\hline $7-9$ & 14 & 27 \\
\hline 10 and more & 10 & 19 \\
\hline \multicolumn{2}{|c|}{ Phase of business idea development } \\
\hline Idea & 0 & 0 \\
\hline Developmental stage & 0 & 0 \\
\hline
\end{tabular}




\begin{tabular}{|c|c|c|}
\hline Prototype & 9 & 17 \\
\hline First revenue & 16 & 30 \\
\hline Growing revenue & 28 & 53 \\
\hline
\end{tabular}

Source: research results

For purpose of this research paper is used a general description of the data that we acquired in our research. In next chapter based on descriptive statistics are data aggregated for the last stage of research, general indicator as market presence and entry modes were used. In the last stage of research, the part of questionnaire was focused on startup position in external environment (table 4); scale from 1 to 5 was used for these indicators as follows:

- Action radius (from 1 - local to 5 - global)

- Segmentation level (from 1 - no segmentation to 5 - customization)

- Position in the external environment (from 1 - weak/on the edge to 5 - market leader)

A key part of questionnaire was focus on mapping changes and shifts in business models. Structure of nine blocks designed by Canvas business model was used. At the end of next chapter are stated the changes of startups business models.

\section{Research synthesis and discussion}

The results of the research show that startups are largely present on the market, in terms of first sales and they are expended transnationally $(75,5 \%$ operate on international markets).

The foreign markets, into which, the Slovak startups are operating, are the European Union countries (Czech Republic, Austria, Germany, Spain, Great Britain, France), the North American markets (USA, Canada), Russia, China, Australia and Brazil (a survey of these countries is the result of a qualitative analysis of the questionnaires throughout the research period). More than $70 \%$ of startups operate on foreign markets, at least within the Central European market. Creating global business from a local business is not an easy or common matter. The process of business internationalization (regardless of whether it is a classic business or a startup) requires not only geographic expansion (like physically occupying new markets) but also expansion associated with the using of information technology. In Table 2 can be observed than more than $80 \%$ of startups after 3 years of existing are in the first sales stage. These startups were able to transform the business idea into a real business.

Table 2. Indicator - Market presence (the last stage of research)

\begin{tabular}{|l|c|c|c|}
\hline \multicolumn{1}{|c|}{ Structure of indicator } & number $(\mathbf{N})$ & $\mathbf{\%}$ & cumulated \% \\
\hline Preparing to enter the market & $\mathbf{2}$ & 3,77 & 3,77 \\
\hline Preparation completed & $\mathbf{7}$ & 13,2 & 16,98 \\
\hline Market entering & 1 & 1,89 & 18,87 \\
\hline First sales & 43 & 81,1 & 100 \\
\hline
\end{tabular}

Source: research results 
The effective and suitable entry mode depends largely on the financial possibilities of the startup, the nature of the product or the service, the distance of the market which startup wants to enter. The selection of the suitable entry mode is influenced by the time possibilities and the growth strategy itself, and preferences of startup founders. Table 3 provides an overview of the structure of basic entry forms that are used by startups. The majority of startups (almost 84\%) are entering foreign markets through cross-border sales, which are largely coordinating in their own direction (more than $67 \%$ of startups use direct sales across borders).

Table 3. Indicator - Entry modes (the last stage of the research)

\begin{tabular}{|l|c|c|c|}
\hline \multicolumn{1}{|c|}{ Structure of indicator } & number $\mathbf{( N )}$ & \% & cumulated \% \\
\hline indirect exporting & 8 & 16,3 & 16,33 \\
\hline direct exporting & 33 & 67,4 & 83,67 \\
\hline franchising & 1 & 2,04 & 85,71 \\
\hline licensing & 6 & 12,2 & 97,96 \\
\hline sale of startup & 1 & 2,04 & 100 \\
\hline
\end{tabular}

Source: research results

Running a business in the global economy is now a current phenomenon. Through a detailed analysis of the selected indicators, we tried to clarify the situation of Slovak startups in the international business space. The results identified the fact that even the Slovak startups have the potential to become globally successful, based on the results of the last phase of the research, $76 \%$ of research sample startups are already operating outside the Slovak Republic and about $30 \%$ of the startups are at the stage of making a profit.

The global expansion represents a huge revenue growth opportunity for companies, and that is the main reason why startups should take the chance. It also allows them to diversify revenue sources, and therefore, the risks. Finally, companies that go global quickly can keep their strategic position as a technical leader and sustain their competitive advantage in an increasingly aggressive market. According the data and output of our research, Slovak startups are able to go international very quickly. Due to indicator "action radius", almost $76 \%$ of sample run international business. The existence of startups in the global economy in very common now. In a detailed analysis of selected indicators, we tried to clarify the situation of Slovak startups in the international business environment. The results show that even Slovak startups have the potential to become globally successful. Many startups in Slovakia are looking for clients and customers abroad directly (through direct sales), the question is how far and in what quality they can analyze the foreign market and capture all the potential of global market opportunities. Slovak startups' most prefer entry form is an export form (mainly indirect sales $-70 \%$ of startups and direct sales of $9 \%$ startups), the licensing is using $11 \%$ startups. Time factor, financial possibilities and the growth strategy of the company, respectively, ideas and preferences of founders and investors usually affect the choice of the suitable entry mode mostly.

According to a recent report from Crane Venture Partners on the internationalization of high-growth startups (more than $88 \%$ being funded or headquartered in the US), almost $90 \%$ of them have an international presence. Even if takes 5.5 years on average for those companies to launch internationally, we have noticed that the more recent the startup is, the sooner it accelerates its global presence. It took more than 10 years for a company 
established before 2000 to go global, while businesses funded between 2006 and 2011 only waited for 3 to 4 years. According to Chotard, 2017 [11] very interesting is how US and non-US companies approach internationalization very differently: "Non-US companies take between 1 and 2 years on average to expand globally. This can be explained by both the smaller size of their home markets and a typically longer technology adoption curve. It's no surprise that the United States still leads the market for tech startups."

The global expansion represents a huge revenue growth opportunity for companies, and that is the main reason why startups take the chance. It also allows them to diversify revenue sources, and therefore, the risks. Finally, companies that go global quickly can keep their strategic position as a technical leader and sustain their competitive advantage in an increasingly aggressive market. We also further analyzed the startup position in the external environment. The following Table 4 gives the general statistical results of three indicators through which was analyze the external environment of startups.

Table 4. Startups position in the external environment

\begin{tabular}{|l|c|c|c|c|c|}
\hline \multicolumn{1}{|c|}{ Indicator } & Number & Average & $\begin{array}{c}\text { Standard } \\
\text { deviation }\end{array}$ & Min. & Max. \\
\hline \multicolumn{5}{|l|}{ The last stage of research } \\
\hline Action radius & 53 & 3,57 & 1,35 & 1 & 5 \\
\hline Segmentation level & 53 & 2,94 & 0,89 & 1 & 5 \\
\hline $\begin{array}{l}\text { Position in business } \\
\text { environment }\end{array}$ & 53 & 3,09 & 1,43 & 1 & 5 \\
\hline
\end{tabular}

The startup action radius largely duplicates the geographical spread of the startup action. Exactly $71.70 \%$ of startups have marked their action radius for Central European, European or Global. Startups are trying to segment their customers largely, almost $80 \%$ of startups segment to several or more segments, $7.55 \%$ startups even use the customization (adaptation of the product to individual customer requirements). The current situation about the position of startup in the business environment is described by the following results: a third of the startups ranked their position as average, one third is considered as a leader and one-fifth of the startup marked their market position as weak. [12]

Table 5 Development of startup business model

\begin{tabular}{|c|c|c|c|c|}
\hline $\begin{array}{c}\text { Key } \\
\text { Partners }\end{array}$ & $\begin{array}{c}\text { Key } \\
\text { Activities }\end{array}$ & $\begin{array}{c}\text { Value } \\
\text { Propositions }\end{array}$ & $\begin{array}{c}\text { Customer } \\
\text { Relationships }\end{array}$ & $\begin{array}{l}\text { Customer } \\
\text { Segments }\end{array}$ \\
\hline Stage $1: 3,83$ & Stage $1: 3,83$ & Stage $1: 4,03$ & Stage $1: 3,92$ & Stage 1: 4,15 \\
\hline Stage $3: 4,51$ & Stage $3: 4,51$ & Stage 3: 4,49 & Stage 3: 4,40 & Stage 3: 4,45 \\
\hline \multirow{2}{*}{$\begin{array}{l}\text { increase } \\
0.70 \text { point }\end{array}$} & increase & increase & increase & increase \\
\hline & $\begin{array}{c}\text { Key } \\
\text { Resources }\end{array}$ & & Channels & \\
\hline
\end{tabular}




\begin{tabular}{|c|c|c|}
\hline $\begin{array}{c}\text { Stage 1: } 3,98 \\
\text { Stage } 3: 4,25 \\
\text { increase } \\
\text { 0.27 point }\end{array}$ & $\begin{array}{c}\text { Stage } 1: 3,58 \\
\text { Stage } 3: 4,15 \\
\text { increase } \\
\text { 0.57 point }\end{array}$ & \\
\hline $\begin{array}{c}\text { Costs Structure } \\
\text { Stage } 1: 4,05 \\
\text { Stage } 3: 4,44\end{array}$ & \multicolumn{2}{|c|}{$\begin{array}{l}\text { Stage } 1 \text { : price } 3,81 \text { quantity } 3,46 \\
\text { Stage } 3 \text { : price } 4,40 \text { quantity } 4,06\end{array}$} \\
\hline increase 0.39 point & \multicolumn{2}{|c|}{$\begin{array}{l}\text { increase of price } 0.59 \text { point } \\
\text { increase of quantity } 0.34 \text { point }\end{array}$} \\
\hline
\end{tabular}

Table 5 summarizes the overall changes in the Canvas business model by comparing the first and final stages with the fact that in each block have been stated a positive development (the calculated change was always a positive increase). The most significant changes have been made in the identification of key partners ( 0.70 points $)$, key activities ( 0.68 points) and revenue streams especially in the identification of product/service price. The lowest positive changes were identified in the block of key resources ( 0.27 points $)$ and costs structure (0.29 points).

Startups that operate globally also have very high dynamics and speed of business action. Results also confirmed that globally operating startups sell their products and services at high prices (or at least higher or comparable to the competition they know about). B. Zagorsek, 2016 [13] confirmed this result, in his research output, stated: "the most interesting result was the identification of a higher price strategy than the competition, which positively influenced the higher number of paying customers." From the Canvas business model, the following fact has been identified: the presence of resources and the presence of processes does not have a significant impact on the startup radius of action. Running a business in the global economy is now a common phenomenon. Through a detailed analysis of the selected indicators, we tried to clarify the situation of Slovak startups in the international business space.

According to the Cambridge Associates investment firm, $40 \%$ of the startup business has a chance for business success [14]. According to the European Association of Business Angels (2017) there are launched about 50 million new projects every year $(137,000$ per day), but $90 \%$ of them fail.

The results identified the fact that even the Slovak startups have the potential to become globally successful, based on the results of the last stage of the research, $76 \%$ of research sample startups are already operating outside the Slovak Republic and about 30\% of the startups are at the stage of making a profit.

\section{Acknowledgement}

This research paper is partial output of project VEGA MŠ SR č. 1/0631/19 "Metamorfózy startupov na ceste za podnikatel'ským úspechom. Metamorphoses of startups on the way for the business success", 2019 - 2021 in 100\% range. 


\section{References}

1. D. McClure, Startupquote. [accessed 08.06.2019] startupquote.com/post/51277392517

2. A. Osterwalder, Y. Pigneur. Business Model Generation. Handbook for visionaries, game changers, and challengers. John Wiley and Sons; 1st edition. ISBN 9780470876411 (2010)

3. S. Blank. What's A Startup? First Principles. [accessed 08.06.2019] https://steveblank.com/2010/01/25/whats-a-startup-first-principles. (2010)

4. Blank, S. Why the Lean Start-up Changes Everything? In Harvard Business Review. Boston: Harvard Business Publishing. ISSN 00178012 (2013)

5. S. Fisher, J. Duane. The Startup Equation. A visual guidebook for building your startup. USA: McGraw-Hill Education, 2016. ISBN 978-0-07-183236-6 (2016)

6. D. L. Yohn, Start-ups needs a minimum valuable brand. In Harvard Business review (2014). [accessed 15.3.2020] https://hbr.org/2014/06/start-ups-need-a-minimumviable-brand (2014)

7. M. Garber, J. Fund. Minimum viable brand for startups. [accessed 12.3.2020] https://medium.com/rga-ventures/building-minimum-viable-brand-for-startups4e834d0608fc

8. A. Afuah, A. Business Models: A Strategic Management Approach. New York: McGraw-Hill/Irwin. ISBN 978-0-07-288364-2 (2003)

9. M. W. Johnson, C. M. Christensen, H. Kagermann. "Reinventing Your Business Model." Harvard Business Review 86, no. 12 (December 2008).

10. A. Osterwalder, Y. Pigneur. Business Model Generation. Handbook for visionaries, game changers, and challengers. John Wiley and Sons; 1st edition. ISBN 9780470876411. (2010)

11. Chotard, L. International Success of Startups Worldwide. [accessed 15.3.2020] https://www.textmaster.com/blog/internationalization-startups-worldwide/ (2017)

12. R. Bednár, K. Procházková, B. Zagoršek. Strategies and Business Models of Startups. Reviewers: Michal Varmus, Katarína Chomová. 1st Edition. Brno: Tribun EU (2018). 122 p. ISBN 978-80-263-1508-7. (2018)

13. B. Zagoršek. Využitie stratégie na dosiahnutie úspechu. In Podnikatel'ské modely a podnikatel'ské stratégie startupov II. Recenzovaný zborník vedeckých prác. Bratislava: Ekonóm, 2016. s 162 - 169. ISBN 987-80-225-4328-6 (201).

14. E. Griffith. Conventional Wisdom Says $90 \%$ of Startups Fail. Data Says Otherwise. [accessed 12.3.2020] http://fortune.com/2017/06/27/startup-advice-data-failure 